\title{
The Effect of Teaching Activities Done by Using Activity Based Posters on the Students' Academic Achievements, Retention Levels in Their Learning ${ }^{i}$
}

\author{
İsmail Coșkun ${ }^{1, *}$, Cevat Eker $^{2}$ \\ ${ }^{1}$ Institute of Educational Sciences, Eskişehir Osmangazi University, Eskişehir, Turkey \\ ${ }^{2}$ Ereğli Education Faculty, Bülent Ecevit University, Zonguldak, Turkey
}

Copyright $\subset 2018$ by authors, all rights reserved. Authors agree that this article remains permanently open access under the terms of the Creative Commons Attribution License 4.0 International License

\begin{abstract}
The aim of the study is to investigate whether the activity based posters have an effect of on the ninth class students' academic achievements and the retention levels in their learning. The research was carried out with 60 students at one of the state schools in The Central Anatolia Region of Turkey in 2015-2016 academic year. Study - "Celebrities" unit teaching - took 6 weeks in both experimental group and control group. This study was conducted according to the "pre-test-post-test control group model" which is from quantitative research methods. The unit of "Celebrities" Achievement Test was developed by the researcher. These data collection tools were implemented at the beginning and the end of the study. Academic Achievement Test was re-implemented 21 days later after study in order to determine the retention levels in their learning. At the end of the research, it is detected that implementation of the activity based posters in English classes makes statistically significant difference for the benefit of experimental groups on the level of academic success.
\end{abstract}

Keywords Posters Based on Activity, Teaching English, Academic Achievement

\section{Introduction}

At the present time, it is necessary to participate actively in teaching activities so that the students can learn better. For this reason, teachers now prefer to use different methods and techniques in which students can be active in the context of student-centered approaches [1], because learning is not transmitting knowledge automatically to students. On the contrary, students are active individuals who shape their own learning activities [2]. In this process, it is important to reconstruct the information for the students by participating effectively in the lesson and making sense of the previous knowledge. Thus, the educational experiences of the students become more permanent with mental transformation and cultural and social experiences and individual gains are enriched with the formation of new ideas [3]. One of the contemporary teaching models based on student-centered teaching is active learning, too [4]. Active learning generally refers to be active in the learning process of students. In this learning process, activities carried out in the classroom are those which the students involve themselves. For example, there are activities such as research studies, problem solving, small group working, cooperative learning, and experiential learning [5].

The purpose of these activities is to get students out of being passive audience and observers and to keep the student into the learning-teaching phenomenon in person. But it is not only to participate simply in the learning process for the learners but also to encourage them to use their mental abilities, to think themselves, to comment on learned topics, and to make relevant decisions in the learning process [6].The student is actively involved in the learning process, directs his / her own learning, uses high-thinking and decision-making skills, and engages in cooperation with friends [7].

In this process which students are active participants, they are responsible for dealing with difficult and complex activities, solving problems instead of dealing with simple activities and problems [8]. It is necessary to look at events from different standpoints, to discover similar and different aspects, to transform into other forms, to grasp the causes, to understand how to predict the past and future possible effects, to keep up with new situations for themselves and to take responsibilities rather than memorizing information [9]. One of the most important features of active learning is to ensure that students learn in collaboration because the collaborative learning includes student-students interaction. Therefore, collaborative learning requires interpersonal skills, 
interpersonal interaction, positive interdependence and being able to move together a subject and the struggle for achieving [10]. In this context, activity-based poster, one of the learning approaches which keep the students active in the classroom, enables them to learn meaningfully during lesson [11]. In recent years, the use of posters has started to take the form of classroom activities [12]. Activity-based poster is a teaching approach that students use to prepare posters by using pictures and texts about a specific topic which they choose. Later, they present poster for their friends and talk about them during the class [13]. In the preparation of activity-based posters, students use graphics, pictures, tables, samples, and their own drawings to make posters attractive [12-14].

Posters include original studies that the students perform on a specific topic with their friends in the classroom. Thus, an authentic learning environment is created in the classroom [15]. In such an environment, students involve in their own activity and they are also in an active process [16]. Therefore; the students learn the knowledge permanently by keeping their learning alive on their own. Thus, the students use library resources effectively, develop critical thinking, group work and presentation skills [17].

The use of activity-based posters as an alternative teaching tool in the classroom is different from hanging on the classroom, library and school walls. So, it has a new quality. The creator of posters used as teaching tools in class are the students who take part in the activity instead of looking at the remarkable images of the posters hanging on the walls or reading the text of them. So, nowadays, when the original works and projects have significant repercussions, students can make their own posters and present them in front of their friends in the classroom environment with such an authentic teaching tool. In terms of these features, posters allow students to become active learners and develop their high level thinking skills [18]. Parallel to these features, the student gains important behaviors and attitudes through a creative poster presentation and they have the opportunity to learn by practicing in such a social environment [17-19-20].

\subsection{What Is a Poster?}

The posters have different definitions according to their usage fields. Posters are the tools which are created a combination of text and pictures and designed for public places. For a moment, it is designed to attract people's attention, to give messages to the intended audience, and to give the impression that the message given in the minds of the people can be turned into the action. In the other words, the aim is to make a sensation and to attract attention to the target audience [21]. For example; selling a product easily to people, increasing the audience of a film, increasing a politician's vote and so on [22].

Posters are attractive, interactive and dynamic visual tools which ideas, research results or news exhibit in a board [23]. Posters are visual communication tools which texts are orally presented [24].The posters on which the texts are shown are scientific posters. Scientists often present their paper in the poster session [23]. These posters contain effective outlines which have the conceptual framework, method, discussion and conclusions of the paper. And these scientific posters contain a brief summary instead of the full text of the published articles. There is no full text [25].

Posters are attractive, colorful learning tools that enrich the learning environment [26]. Teachers in different disciplines in learning and teaching environments also use posters extensively to convey various information and messages to students. In present-day education system, poster presentations are used in classrooms or schools so that students can participate more actively in the education system. According to Baird [27], classroom poster presentations are seen as an effective alternative rather than traditional research assignments. Poster presentations are suitable for all classes and there are some benefits. For example; they enhance cooperative learning, encourage creativity and independent learning. And they also enhance research and communication skills. So, posters will lighten teachers' burden in classroom.

Students discover specific content topics as well as improving presentation and communication skills. Poster presentations are task-based activities in which students develop research topics, ask questions, collect and analyze information, and present their peers [28]. Allan and Bailey [14] describe the role of student-made posters as a communication tool that conveys a wider audience mass as a result of workplace-based projects in their research which they conduct.

\subsection{The Use of Posters in Classroom Environments}

The use of visual objects constitutes a large part of the experience in the learning environment [29]. Researches show that visual materials constitute $90 \%$ of brain stimuli and visual memory constitutes two-thirds of the brain [30]. So, as the assimilation of knowledge is a key to the success of the education system, educational settings need to include rich visual materials [26]. The most important teaching material that enriches visually the learning environment is the poster [31].

When a student opens his book, he sees the picture in the first page, in the other word, when a student enters the classroom, he notice the poster on the wall. Therefore; posters create a more stimulating and challenging learning environment [32]. According to Osa and Musser [26], posters are used to 1) show a concept or something, 2) show an operation, 3) distinguish between similar things and 4) attract attention of the student in the classroom environment. For example the soil types can be shown through a poster in order that the students can understand better the topics in the geography lesson. In the same way, 
a teacher who presents water cycle during the lesson teaches via a poster which makes the learning easier and clearer.

Hubenthal [31] has made important suggestions to educators so that the posters used in the classroom environment can be efficient:

1. Attitudes and behaviors of the students should be affected by hanging the posters.

2. One should be selective about the poster in the classroom. Especially, teachers should pay attention to the types and sizes of visuals as well as the explanatory texts

3. Posters related to inter-unit issues should be replaced and hanged on the other side of the class. The teacher should increase the students' inquiries and emphasize connections between the units by the help of the posters.

4. A few posters in the units should be used at the same time to highlight the key subjects and students should be concentrated on these key subjects.

5. Activity-based topics that will enable the student's mind and thinking skills should be included. Visual elements should be supported in this direction.

\subsection{The Use of Activity Based Posters}

Activity-based posters are those which are created by finding pictures and photos from different sources and pasting on a card and adding verbal information about the subject which the students search [33]. Posters are visual tools that allow the students to reach the knowledge, to summarize and to use it and to develop communication skills [34]. In addition, the posters are meaningful communication tools which the students expose their own drawings and support it with visual elements [35].

Activity-based posters are composed of lesson subject and pictures related to it. The most important feature of these posters is that students create their own products. There are constant teacher-students interaction and students-students interaction. Students have a constant desire to improve their own work. Furthermore, there is also the excitement of presenting posters prepared by students [23]. The use of activity-based posters is suitable for all classes. It also provides cooperative learning, gives opportunity to the students to have creativity and independent thinking. Moreover, it enhances research and communication skills and alleviates the teacher's work of education [27]. Posters provide meaningful learning by making it easier for the students learn the subject [34].

Preparing and presenting posters is a valuable learning experience because it is structured within a specific purpose [35]. Developing research skills, critical thinking and communication skills are important purposes for the students who prepare poster and presentation them. Developing research skills, critical thinking and communication skills are the most important goals of preparing poster and presenting [16-17]. Jost [20] emphasizes the important goals of preparing poster and being presented. The first goal is to improve the communication skills of students in an authentic environment. The second one is that students should acquire knowledge on different subjects and gain dynamism in group work.

The poster work which is practiced with great enthusiasm increases the students' motivation towards the lesson. This is the most important feature of posters. Students interact with their classmates and teachers while preparing posters [23]. Posters are excellent tools to improve especially communication skills. In educational environment, the posters are of great value in establishing a communication environment in which the teachers use various learning styles while teaching in the classroom [13].

Since the posters are intended to be applied, students establish links between abstract subjects and the real World easily [23]. Posters help the students to develop critical thinking skills, to encourage independent learning, to be knowledgeable about a particular topic, and to be effective in the classroom besides strengthening communication skills. And so, it is a factor in having managerial skills about the future profession [36]. According to Chabeli [32], poster presentations facilitate students' participation in group work and increase student's independence and feelings of ownership besides developing the creative, critical and reflective thinking skills of the student by becoming competent about a subject

According to Berry and Housten [37], posters cause to develop positive emotions and attitudes towards the lesson. During the preparation of the poster, the students increase their enthusiasm and strength the mental competence. Moreover, the poster causes the students to have the sense of optimism and determination. At the same time, the use of technology in this process increases the sense of competence of students. It is seen that the posters develop feelings of self-esteem in individual studies and feelings of cooperation in group studies [38]. In addition to these, they provide a sense of accomplishment as posters have a compelling effect on a subject [39].

Another benefit of the posters is that students improve their research skills. Students will have to find additional resources to complete their posters. So, they will reach different sources in libraries. This will leave a better understanding of the library and students will gain the ability to reach quality and reliable resources for both their own lives and their lessons [35]. In addition to these, the completion of posters and the use of them in classroom environment provide the students to gain a sense of discovery and to have academic skills [19].

Besides the completion and exhibition of students' posters, it is also important to present it briefly and clearly for peer groups. These presentations contribute the 
students to improve communication skills and socialize [37]. Posters allow students to improve their ability to ask questions and respond by sharing their own subject while poster presentations allow students to see each other's posters and to learn about different topics [35]. Therefore, students should demonstrate their performance by providing a suitable environment for presenting the posters prepared by the students in the classroom environment [40].

\subsection{The Importance of Research}

In recent years, posters, as classroom activities and presentations, have begun to take place in classrooms as an alternative learning tool [16]. They learn new information, discover relationships between the subjects and enable to bring out creative products by combining new information with their old information while posters that students help them review information about the subject [17]. With this research, it is aimed to investigate the effect of posters prepared for activity based activities on learning products and attitudes and levels of retention and these studies are aimed to light up on the work to be carried out from now on.

When the researches which were carried out before are examined (Altıntaş et al. [16], Tapp and Martin, [36], Deutch, [41], Lane[42], Mulnix and Penhale [43], Berry and Nayman [44]), the studies which the effect of posters were prepared for activity based activities on learning products, attitudes and levels of retention haven't been reached. In this respect, it is thought that this study will be a guide and resource for English teachers to use activity-based posters in teaching English. As this research has a feedback quality, it is expected to shed light on whether activity based activities can be suggested and used in educational environment while preparing the curriculum for those who work in the Ministry of National Education and the educational researchers.

This study has the importance to understand whether the teaching method with activity based poster is more effective than instruction based on the teacher's guide book and course book on being taught English vocabulary and grammar and speaking and writing. The hypotheses of the study are:

1. There is no significant difference between the pre-test academic achievement scores of the control group and the pre-test academic achievement score of the experimental group.
2. There is a significant difference in favor of the post-test between the pre-test academic achievement score of the control group and the post-test academic achievement score of the control group.

3. There is a significant difference in favor of the post-test between the pre-test academic achievement score of experimental group and the post-test academic achievement score of the experimental group.

4. There is a significant difference in favor of experimental group between the post-test academic achievement scores of the experimental group and the post-test academic achievement score of the control group.

5. There is no significant difference between the post-test academic achievement of experimental group and the retention test results of the experimental group.

6. There is no significant difference between the post-test academic achievement of control group and the retention test results of the control group.

7. There is a significant difference in favor of experimental group between the retention test scores of the experimental group and the retention test score of the control group.

\section{Method}

\subsection{Research Model}

This research was conducted to determine the effectiveness of activity-based posters used in teaching English lessons on academic achievement of students and levels of retention of them. This study was conducted according to the "pre-test-post-test control group model" of quantitative research methods. In pre-test - post-test control group model; there are two groups created with neutral assignment. Thus, an experiment and a control group were established in this research and the measurements were made before and after the experiment in both groups. In the model, the result of the pre-tests applied to the groups before applications enable to determine groups' similarity levels and post-test results help to interpret the results [45].

The experimental design of the study is given in Table 1 .

Table 1. The experimental design of the study

\begin{tabular}{|c|c|c|c|c|}
\hline \multirow{2}{*}{\multicolumn{2}{|c|}{$\begin{array}{l}\text { PRE-TEST } \\
\text { Unit 5, Celebrities }\end{array}$}} & \multirow{2}{*}{$\begin{array}{c}\text { EXPERIMENTAL OPERATION } \\
(6 \text { Week }) \\
\end{array}$} & \multirow{2}{*}{\multicolumn{2}{|c|}{$\begin{array}{l}\text { POST-TEST } \\
\text { Unit } 5, \text { Celebrities }\end{array}$}} \\
\hline & & & & \\
\hline Experimental group & $\begin{array}{c}\text { AAT } \\
\text { I }\end{array}$ & $\begin{array}{l}\text { The use of activity-based posters in addition to the use of teacher's guidebook, } \\
\text { course books and workbooks }\end{array}$ & $\begin{array}{c}\text { AAT } \\
\text { II }\end{array}$ & $\begin{array}{l}\text { RT } \\
\text { III }\end{array}$ \\
\hline Control Group & $\begin{array}{c}\text { AAT } \\
\text { I }\end{array}$ & The use of teacher's guidebook, course book and workbooks & $\begin{array}{l}\text { AAT } \\
\text { II }\end{array}$ & $\begin{array}{l}\text { RT } \\
\text { III }\end{array}$ \\
\hline
\end{tabular}

Note: Academic Achievement Test (AAT), Retention Test (RT). I: Pre-test application II: Post-test application, III: Retention-test application 
This research was conducted in the second semester of the 2015-2016 academic years. It took the 6-week period from March 7 to April 15. The "Celebrities" Unit was included in the scope of the study. The academic achievement test was applied to the students of the experimental group before research application. In the implementation phase, the activity-based posters were prepared and presented by the students in addition to the use of teacher's guidebook, course book and student workbooks in the classroom. Students brought paper, colored pencils, colored cartons, etc. materials and visuals related to the subject into the classroom in order to use them in poster making. Pre-tests were applied to the control group as well as in the experimental group. Then the course was taught according to only the teacher's guide book, course books and student workbooks. In the implementation, students have only benefitted from textbooks and workbooks. After 6 weeks, academic success test was applied to experimental and control group about the unit as a post-test. A retention test was carried out on May 6th, 2016 after 21 days of follow-up.

\subsection{Applicants}

The application group of this study constitutes a total of 60 students who were studying at the 9th Grade in an Anatolian High School with middle level students in Eskişehir, in Turkey.

\subsection{Data Tools}

Academic achievement test was used as data collection tool to obtain research data.

\subsubsection{Academic Achievement Test}

The achievement test which was related to the subjects in the 9th grade "Celebrities" unit was prepared by the researcher in order to recognize the success levels of students before application and to determine the effect of the use of activity-based posters on students' academic success and retention in the process of teaching English.

The sign of whether the questions that make up the test are sufficient in measuring the behavior to be measured in terms of quantity and quality is coverage validity. A test with coverage validity includes a good example of the behavior to be measured. This type of validity requires balanced distribution of subjects and behaviors to be measured [46]. For this reason, a total of 40 questions were prepared for the 12 acquisition of the "Celebrities" unit according to the intensity of the topics in the unit. In the prepared achievement test, necessary adjustments were made by taking into consideration the opinions of field experts and English teachers.

In order to determine the reliability of the test, the achievement test was applied to a total of 147 tenth grade students from 5 different high schools in Çifteler town of Eskişehir province. The students in the plot study were similar to experimental group in the terms of academic level. The obtained data were analyzed with the Iteman program and the reliability studies were performed. As a result of the item analyzes, 15 items which the strength of distinctiveness was low were removed from the test by considering the coverage scope of the test. To ensure content validity of the test, it has been paid attention to whether each question item is sufficient to measure the target behavior in terms of content and quality. As a result of the item analyzes, substances with low distinctiveness indexes were removed from the test and a final test consisting of 25 questions was created. Final test statistics are given in the table below.

Table 2. Statistical results of the final test of the "Celebrities" unit

\begin{tabular}{|c|c|c|c|c|c|}
\hline The Number of Students & The Number of Question & $\overline{\mathrm{x}}$ & SS & KR-20 & Average Difficulty of the Test \\
\hline 147 & 25 & 21,102 & 7,681 & 0,868 & 0,528 \\
\hline
\end{tabular}

When Table 2 is examined, the item analysis values are seen according to the results obtained from 147 students. It is determined that the arithmetic average of the test is 21,102 , standard deviation of the test is 7,681 and the KR-20 reliability of the test is 0,868 . And this result indicates that the reliability of the test is high. The average level of difficulty of the questions in the test was 0.528 . According to the findings obtained, it is seen that the items of the test has moderate difficulty. The questions are neither difficult nor easy. It is intended that question items on a academic achievement test are of different difficulty levels and the level of difficulty is around 0.50 [47].The test is acceptable to apply to groups. In the difficulty index, 19th, 27th and 29th questions were removed from the test because they were very easy. Questions 12 and 20 are quite difficult.

The discrimination of a test increases the validity of that test. If the discrimination index of the items is $\geq 0.40$, the item is "very good"; if it is between 0.30 and 0.39 " quite good '; if it is between $0,20-0,29$, the item " can be used in obligatory situations but it needs to be developed "; If it is $\leq 0,19$ the item is very weak, if correction cannot be improved it should be removed from the test "[48-49]. It was observed that the item discrimination index of 10 questions in the test was lower than 0.30 , and it has been decided that it is not appropriate to include the questions $3,5,6,12,13,20,28,31,33,36,37,38$ in the test.

According to this, item difficulty index and item discrimination index were given in the table 2 for the final academic achievement test of 25 questions after 15 question items were taken out. The highest score that can be taken from the final test is 25 and the lowest score is zero. 
Table 3. Item Analysis for the "Celebrities" Unit Final Academic Achievement Test

\begin{tabular}{|c|c|c|}
\hline Item & item difficulty index (pj) & item discrimination index (rjx) \\
\hline 1 & ,483 & ,402 \\
\hline 2 & ,701 & ,496 \\
\hline 3 & ,687 & ,456 \\
\hline 4 &, 531 &, 579 \\
\hline 5 & ,422 & ,315 \\
\hline 6 &, 578 & ,469 \\
\hline 7 &, 517 &, 529 \\
\hline 8 &, 510 &, 534 \\
\hline 9 &, 524 & ,479 \\
\hline 10 & ,469 & ,637 \\
\hline 11 &, 517 & ,493 \\
\hline 12 & ,646 &, 521 \\
\hline 13 &, 585 &, 383 \\
\hline 14 & ,483 & ,629 \\
\hline 15 & ,456 &, 509 \\
\hline 16 &, 517 & ,419 \\
\hline 17 &, 721 & ,486 \\
\hline 18 &, 558 & ,417 \\
\hline 19 &, 354 &, 385 \\
\hline 20 & ,463 & ,407 \\
\hline 21 &, 735 &, 511 \\
\hline 22 &, 524 & ,499 \\
\hline 23 & ,469 &, 598 \\
\hline 24 & ,565 &, 501 \\
\hline 25 & ,537 & ,428 \\
\hline
\end{tabular}

\subsection{Data Collection Process and Application}

This study was conducted in the English course between March 7th and April 15th, 2016 in the second semester of the 2015 - 2016 academic year. The application was carried out for a period of 6 weeks. In this study, "Celebrities" unit was taught to 9th grade students. This unit includes following grammar structures: 'adjectives', 'comparatives and superlatives', 'jobs', and physical and 'personality appearances'.

Pre-test academic achievement test was applied to both experimental group and control group before application. After six weeks of practice, a post-test academic achievement test was applied to both the experimental group and the control group. After the application completed, a retention test was applied to the experimental and control group on May 6th, 2016, after 21 days.
Table 4. The Study Implementation Plan

\begin{tabular}{|c|c|c|}
\hline Period & Experimental group & Control group \\
\hline 1. week & $\begin{array}{c}\text { Pre-test application } \\
\text { Asking about and describing people's appearances and } \\
\text { characters }\end{array}$ \\
\hline 2. week & $\begin{array}{c}\text { Asking about and describing people's appearances and } \\
\text { characters }\end{array}$ \\
\hline 3. week & \begin{tabular}{c} 
İdentifying people \\
\hline 4. week
\end{tabular} & Comparing characteristics and appearances(Comparative) \\
\hline 5. week & Comparing characteristics and appearances (Superlatives) \\
\hline 6. week & $\begin{array}{c}\text { Expressing opinions } \\
\text { (Agreeing, disagreeing, etc....) } \\
\text { Post-test application }\end{array}$ \\
\hline & After the application was completed, a retention test \\
\hline
\end{tabular}

\section{Experiment Group Operations}

- The academic achievement test was administered by the researcher before the application.

- The students were given information about what the poster is, how to prepare it, how to interpret it, how to use it together with visuals.

- Course teacher conducted the lesson according to poster preparation and presentation activities in accordance with the current curriculum and the plan outlined in the teacher's guide book,

- The students had been said that appropriate materials such as ready-made paintings, photographs, colored cartons, colored picture pens, glue, file papers to be used for making posters.

- Brief information about the subject was given to the students for 40 minutes (one lesson hour) before starting the poster production. Then students were asked to prepare posters on the topic in groups. During the course, students had prepared posters related with the topic. The poster preparation time was set at 120 minutes (three lesson hours).

- Students used notebooks, books, workbooks and dictionaries during the lesson.

- The students used the pictures and notes they had obtained from various visual sources when preparing posters. Besides, they used their own drawings and shapes in the posters.

- During the poster preparation process, students were constantly interacting with each other and collaborated with each other in both the subject and the poster preparation process. When necessary, they asked each other questions and exchanged information about the subject.

- Prepared posters were presented to classroom in turn. The duration of the presentation was 80 minutes (two teaching hours). The students who gave the poster presentation were asked by their friends and opinions were expressed about poster. 
- This study continued regularly for 6 weeks.

- After the application was over, the academic achievement test was applied to learn the effect of the posters on the students. After 21 days, a retention test was applied to the experimental group to learn the effect of the posters on retention.

\section{Control Group Operations}

- The academic achievement test was administered by the researcher before the application

- $\quad$ Before each lesson, the teacher taught 36 hours of lessons in total for 6 weeks on the basis of the daily plan about subject matter in the course book, the student workbook and teacher's guide book.

- $\quad$ Teaching unit topics were studied with the method and techniques given in the guide and by adhering to the textbook as instructed in the guidebook. Materials recommended in the annual curriculum were used.

- After the application was over, the academic achievement test was applied. After 21 days, a retention test was applied to the experimental group to see the effect of this method in English teaching on retention.

\subsection{The Analysis of Data}

The data obtained from the academic achievement test were transferred to the statistical program and statistical evaluations were made. In the selection of analysis method to be used for data analysis, the assumptions of parametric tests have been firstly tested. The Shapiro Wilk normality test was preferred in the cases which the data size is less than 50 for normal distribution [50]. According to the normality test results, all test scores are normally distributed. T-test was used to test whether the scores obtained from the academic achievement test and the retention test between the experimental and control groups were meaningful.

\section{Findings and Results}

In this chapter, findings and results of the academic achievement test are organized according to research hypotheses.

\subsection{Findings about the First Hypothesis}

The first hypothesis of the research was expressed "There is no significant difference between the pre-test academic achievement scores of the control group and the pre-test academic achievement score of the experimental group." The results of the first hypothesis are given in table 5 .

Table 5. Comparison of academic achievement pre-test scores of students in the experimental and control groups

\begin{tabular}{|c|c|c|c|c|c|c|}
\hline Academic achievement test & $\mathbf{N}$ & $\overline{\mathbf{X}}$ & SS & sd & t & p \\
\hline Experimental groups & 30 & 9.63 & 4.38 & 58 & 1.6 & 0.11 \\
\hline Control Group & 30 & 8.03 & 3.28 & & & \\
\hline
\end{tabular}

$\mathrm{p}<0,05$ meaningful.

As it is stated in Table 5, it was found that the mean score of academic achievement before the experimental group started to practice was ( $\overline{\mathbf{x}}=9.63)$, and the standard deviation value was ( $\mathrm{SS}=4.38)$. It was found that the mean score of academic achievement of the control group was $(\overline{\mathbf{x}}=8.03)$, and the standard deviation value was $(\mathrm{SS}=3.28)$. At the end of pre-testing of the groups, $t$ test was used to determine whether there was a significant difference between the scores obtained and it was found that there was no statistically significant difference with the value obtained [p $<0.05]$. That is, it can be said that the experimental group and the control group are similar in terms of academic achievement scores before the experiment.

\subsection{Findings about the Second Hypothesis}

The second hypothesis of the research was expressed. "There is a significant difference in favor of the post-test between the pre-test academic achievement score of the control group and the post-test academic achievement score of the control group." The findings of this hypothesis are given in table 6. T-test was used to test whether the scores obtained from the pre-test and post-test of the control group were statistically significant and the results are given in Table 6 .

Table 6. Comparative results of pre-test and post-test academic achievement tests applied to control group

\begin{tabular}{|c|c|c|c|c|c|c|}
\hline Achievement tests & N & $\overline{\mathbf{X}}$ & SS & sd & t & p \\
\hline Control Group Pre-test & 30 & 8.03 & 3.28 & 29 & 4.8 & 0.00 \\
\hline Control Group Post-test & 30 & 13.03 & 4.00 & & & \\
\hline
\end{tabular}

$\mathrm{p}<0,05$ meaningful. 
As it is stated in Table 6, it was found that arithmetic mean of the academic achievement pre-test scores of control group students was $(\bar{x}=8.03)$, and the standard deviation value was $(\mathrm{SS}=3.28)$. And it was also found that arithmetic mean of the academic achievement post-test scores of control group students was ( $\bar{x}=13.03)$, and the standard deviation value was $(\mathrm{SS}=4)$. The difference between the pre-test and post-test scores of the control group was compared with the $t$ test and it was found there was a significant difference with the value obtained $(t=4.8)$ and $p<0.05)$. According to these results, it can be said that teaching with the teacher's guidebook, textbook and workbook is positively efficient in the success of the student.

\subsection{Findings about the Third Hypothesis}

The third hypothesis of the research was expressed " 3 . There is a significant difference in favor of the post-test between the pre-test academic achievement score of experimental group and the post-test academic achievement score of the experimental group." T-test was used to test whether the scores obtained from the pre-test and post-test of the experimental group were statistically significant and the results are given in Table 7.

Table 7. Comparative results of pre-test and post-test academic achievement tests applied to experimental group

\begin{tabular}{|c|c|c|c|c|c|c|}
\hline & $\mathbf{N}$ & $\overline{\mathbf{X}}$ & $\mathbf{S S}$ & $\mathbf{s d}$ & $\mathbf{t}$ & $\mathbf{p}$ \\
\hline Experimental Group Pre-test & 30 & 9.63 & 4.38 & 29 & 9.19 & 0.00 \\
\hline Experimental Group Post-test & 30 & 19.8 & 4.71 & & & \\
\hline
\end{tabular}

$\mathrm{p}<0,05$ meaningful.

As it is stated in Table 7, it was found that arithmetic mean of the academic achievement pre-test scores of Experimental group students was ( $\overline{\mathbf{x}}=9.63)$, and the standard deviation value was $(\mathrm{SS}=4.38)$. And it was also found that arithmetic mean of the academic achievement post-test scores of Experimental group students was $(\overline{\mathbf{x}}=19.08)$, and the standard deviation value was ( $\mathrm{SS}=4,71)$. The difference between the pre-test and post-test scores of the control group was compared with the $t$ test and it was found there was a significant difference with the value obtained $(t=9.19)$ and $\mathrm{p}<0.05$ ). According to these results, it can be said that teaching which the activity-based posters are used is positively efficient in the success of the student. That is, the teaching style applied to the experimental group provides a significant increase in success.

\subsection{Findings about the Fourth Hypothesis}

The fourth hypothesis of the research was expressed "There is significant difference in favor of experimental group between the post-test academic achievement scores of the experimental group and the post-test academic achievement score of the control group." T-test was used to test whether the scores obtained from the pre-test and post-test of the experimental group were statistically significant and the results are given in Table 8.

Table 8. Comparative results of post-test academic achievement tests applied to experimental group and control group

\begin{tabular}{|c|c|c|c|c|c|c|}
\hline & $\mathbf{N}$ & $\overline{\mathbf{X}}$ & $\mathbf{S S}$ & $\mathbf{s d}$ & $\mathbf{t}$ & $\mathbf{p}$ \\
\hline Experimental Group Post-test & 30 & 19.8 & 4.71 & 58 & 5.99 & 0.00 \\
\hline Control Group Post-test & 30 & 13.00 & 4.00 & & & \\
\hline
\end{tabular}

$\mathrm{p}<0,05$ meaningful.

As it is stated in Table 8, it was found that arithmetic mean of the academic achievement post-test scores of Experimental group students was ( $\overline{\mathbf{x}}=19.8$ ), and the standard deviation value was ( $\mathrm{SS}=4.71)$. Arithmetic mean of the academic achievement post-test scores of control group students was ( $\overline{\mathbf{x}}=13.00$ ), and the standard deviation value was $(\mathrm{SS}=4.00)$. The difference between academic achievement post-test scores of the control group and experimental group was compared with the $t$ test and it was found there was a significant difference with the value obtained $(t=5.99)$ and $[p<0.05]$. According to these results, it is seen that the average score of the academic achievement post-test of the students in the experimental group is higher than the students in the control group.

There was a significant difference between the experimental and control groups according to the achievement post-test applied for the English course after the application [ $\mathrm{t}(58)=5.99 ; \mathrm{p}<.05]$. That is, after the activity-based poster teaching applied to the group, students achieved a meaningful change in favor of the experimental group. According to the results obtained from Table 8 , the activity-based poster teaching is more effective than the teaching with guide book, course book, workbook, it can be said that the increase in the academic achievement of the students contributes positively. 


\subsection{Findings about the Fifth Hypothesis}

The fifth hypothesis of the research was expressed "There is no significant difference between the post-test academic achievement of experimental group and the retention test results of the experimental group." T-test was used to test whether the scores obtained from the retention test and post-test of the experimental group were statistically significant, and the results are given in Table 9.

Table 9. Comparative results of the academic achievement post-test and retention test applied to experimental group

\begin{tabular}{|c|c|c|c|c|c|c|}
\hline & $\mathbf{N}$ & $\bar{X}$ & SS & sd & t & p \\
\hline Experimental group post-test & 30 & 19.8 & 4.71 & 29 & 1.35 & 0.18 \\
\hline Experimental group retention test & 30 & 21.56 & 4.67 & & & \\
\hline
\end{tabular}

$\mathrm{p}<0,05$ meaningful.

As it is stated in Table 9, it was found that arithmetic mean of the academic achievement post-test scores of Experimental group students was ( $\overline{\mathbf{x}}=19.8)$, and the standard deviation value was $(\mathrm{SS}=4.71)$. Arithmetic mean of the academic achievement post-test scores of Experimental group students was $(\overline{\mathbf{x}}=21,56)$, and the standard deviation value was $(\mathrm{SS}=4.67)$. The difference between retention test scores and academic achievement post-test scores of the experimental group was compared with the $t$ test and it was found there was a significant difference with the value obtained $(\mathrm{t}=1.35)$ and $[\mathrm{p}<0.05]$. According to these results, it is seen that it can be said that the teaching method in which activity-based posters are used positively contributes that the students remember the information in English classes.

\subsection{Findings about the Sixth Hypothesis}

The sixth hypothesis of the research was expressed "There is no significant difference between the post-test academic achievement of control group and the retention test results of the control group." T-test was used to determine whether the scores obtained from the retention test and post-test of the control group were statistically significant, and the results are given in Table 10.

Table 10. Comparative results of the academic achievement post-test and retention test applied to control group

\begin{tabular}{|c|c|c|c|c|c|c|}
\hline & N & $\bar{X}$ & SS & sd & t & p \\
\hline Control group Post-Test & 30 & 13.03 & 4.00 & 29 & 0.17 & 0.86 \\
\hline Control group retention test & 30 & 13.20 & 4.20 & & & \\
\hline
\end{tabular}

$\mathrm{p}<0,05$ meaningful.

As it is stated in Table 10, it was found that arithmetic mean of the academic achievement post-test scores of control group students was $(\overline{\mathbf{x}}=13.03)$, and the standard deviation value was $(\mathrm{SS}=4.00)$. Arithmetic mean of the academic achievement post-test scores of control group students was ( $\overline{\mathbf{x}}=13.20)$, and the standard deviation value was (SS $=4.20$ ). The difference between retention test scores and academic achievement post-test scores of the control group was compared with the $t$ test and it was found there was a significant difference with the value obtained $(t=0,17)$ and $[p<0.05]$.

According to these results, it is seen that it can be said that the teaching method in which course book, workbook and guidebook are used positively contributes that the students remember the information in English classes.

\subsection{Findings about the Seventh Hypothesis}

The seventh hypothesis of the research was expressed "There is significant difference in favor of experimental group between the retention test scores of the experimental group and the retention test score of the control group." A retention test was applied to the students 21 days after the application. T-test analysis for independent / unrelated samples was used to test whether the scores obtained from the retention tests were statistically significant, and the results are given in Table 11.

Table 11. The results of the comparative analysis of the retention test of the experimental and control groups

\begin{tabular}{|c|c|c|c|c|c|c|}
\hline & $\mathbf{N}$ & $\bar{X}$ & SS & sd & t & p \\
\hline Experimental Group Retention Test & 30 & 21.56 & 4.67 & 58 & 7.28 & 0.00 \\
\hline Control Group Retention Test & 30 & 13.20 & 4.20 & & & \\
\hline
\end{tabular}

$\mathrm{p}<0,05$ meaningful. 
As it is stated in Table 11, it was found that arithmetic mean of the academic achievement retention test scores of experimental group students was $(\overline{\mathbf{x}}=21.56)$, and the standard deviation value was $(\mathrm{SS}=4.67)$. Arithmetic mean of the academic achievement retention-test scores of control group students was $(\overline{\mathbf{x}}=13.20)$, and the standard deviation value was $(\mathrm{SS}=4.20)$. The difference between retention test scores of academic achievement experimental group and control group was compared with the $t$ test and it was found there was a significant difference with the value obtained $(t=7.28)$ and $[\mathrm{p}<0.05]$. According to these results, it is seen that the average score of the retention test of the experimental group students is higher than the scores of the control group students. There was a significant difference in favor of the experimental group between the experimental and control groups according to the retention test after the application for the English course.

According to these results, it can be said that preparing their own poster and presenting it can cause learned information to be more permanent as there was a significant difference in favor of the experimental group in the retention test performed after 21 days from the post-test. Students can remember better in the activity-based poster teaching on the contrary to the teaching methods and techniques mentioned in the teacher's guidebook in the activity-based poster teaching.

\section{Results and Discussion}

Academic achievement test was applied to the experimental and control group before and after the application. Although the experimental and control groups were similar in terms of academic achievement scores with pre-implementation, it is seen that the average of the scores of the students in the post-test group is higher than those of the control group after the implementation of the practicing the activity based on poster. Therefore, it can be said that teaching English with activity-based posters applied to the experimental group is more effective than teaching conducted with guidebook, course book and workbook. So, activity based poster has a positive effect on the increase of the academic achievement of the students.

With the teaching of activity-based posters, the success of the students in the experimental group are similar to the results of the researches conducted by Mulnix \& Penale [44], Bracher et al. [17], Berry ve Nayman [42], Chaznava et al. [23], Brown \& Burroughs [51], Tanner \& Chapmen [28], Hasio [39] and Eker [34]. It can be stated that making posters in activity and presenting them to friends in class can contribute to meaningful learning by constructing self-information with teacher guidance and providing effective participation. This result is consistent with the results of the research done by Brown \&
Burroughs [51], Berry \& Nayman [42], Mulnix \& Penhale [44], and Eker [34]. When students prepare and present a poster about unit topics in the learning process, they reconstruct the learned topics in their minds, thus they enhance academic achievement [34]. As a result, the students move their minds and they realize meaningful learning thanks to activity based posters [39].The students have in-depth knowledge about a subject through the teaching conducted with the activity based on poster. In addition, they are more effective and successful in their activities when they are active rather than the other methods [44].

It can be said that preparing posters increases the students' motivations in English course. One of the most important psychological concepts in education is motivation. Motivation is defined as the power that drives energy and directs it to a target [52]. Students decide how to make a poster with activity-based poster teaching. He sets a goal to prepare a good poster and struggles to be successful. On the other hand, students have the opportunity to receive continuous feedback from their teacher as they prepare the post in the classroom environment. Therefore; students are actively involved in the preparation of activity-based poster teaching. They gain positive emotions such as a sense of ownership and achievement [17-28]. The research conducted by Chaveznava et al [23], confirms these results. Poster presentations increase students' motivation towards the lesson, which contributes positively to the increase in academic achievement.

The research done by Baird [27] shows similar results with this research. Baird [27] stated that classroom-based posters are more beneficial than other methods, enhances students' achievement. In addition, he also points out the following positive features: The students who make classroom-based poster presentations learn from each other by exchanging ideas with their friends while preparing the posters. They develop communication skills because they interact with each other. Students help their friends to find their mistakes by catching the opportunity to evaluate their posters. Thus, the use of activity-based posters provides a positive contribution to increase academic achievement of students.

After 21 days from the application, the retention test was applied to the students of the experimental and control groups. A significant difference was found in favor of the experimental group according to the results obtained from the retention test. According to this result, the experimental group which activity-based posters were applied in English classes remember the subjects better than the control group that is taught with the course books and teaching methods and techniques indicated in the guide book. As a result, the activity based on poster, the teaching applied to the experimental group, is more effective than the teaching applied to the control group.

The results of the retention test applied to students are 
parallel with the results of previous studies about activity-based poster teaching (Crowley-long [15]; Bracher et al. [17]; Berry \& Nayman [42]; Akıster et al, [40]; Köklü, [12]; Osa ve Musser [26] Jost [20]; Allan \&Bailey [14]; Doğan et al. [53]. There may be some reasons why the activity-based posters applied to the experimental group provide a meaningful increase in academic success. First, the students used the images continuously while preparing their posters and they created a meaningful whole from these images and put forward a poster of their own. According to Eker [34], the students learn more easily with interesting images. Students are attracted to interesting and different visuals, so they understand information which is complex and difficult to learn and keep it in memory for a long time. In this context, Osa \& Musser [42] find out the results parallel to this research and they state the images are important for learning the information and remembering it permanently.

Secondly, preparing posters in class environment and presenting them to friends develop communication skills. This is why the experimental group is more successful than the control group and they can remember the topics for a longer time. In parallel with this result, Altıntaş et al. [37] found that students who do poster projects develop communication skills and get a critical perspective in contrast to traditional homework students. Poster presentations in the classroom and open-ended questions that students ask each other increase classroom interaction as students are more active. Thus, students learn the subjects better.

Moreover, it is thought that the students which create poster reach different sources. So they develop research skills. So, students who prepare their own posters are more successful than those who have taught with the methods suggested in the teacher's guidebook. Hunter [54] found parallel result to with this research. The students who prepare an activity-based poster both reach the different sources before the lesson and acquire different information and visuals and use their own course materials in the classroom. As a result, they enable to increase their academic achievements.

It is believed that they remember what they learn formerly with the effective participation of the students in the poster preparation process, the use of learning methods by doing, and reaching different sources. These studies have parallel results with those of Dogan et al. [54], Crowley-long [15] \& Köklü [12]. According to Brooks \& Brooks [55], a teacher should devote time to working class activities, such as classifying, analyzing, making predictions and putting out a unique product. Because, these features include mental activities such as establishing links between topics, deep understanding of texts and creating something original. Thus, the student has the ability to keep things in mind for a long time and to remember, even reuse [7]. As the students are actively involved in the process, learning becomes permanent and the students develop academic knowledge with activity based poster contrary to the teaching with the methods and techniques mentioned in the teacher's guide book [15] because the students learn the subject matter in detail through this process [53]. The students are able to put out unique products and thus learning is permanent with well-planned poster preparation activities.

In addition, it is thought that experimental group students prepare the poster and presentation in groups in the classroom environment and so increased the permanence of students in their learning and as a result, they have increased their retention in their learning. In the literature, researches which are parallel to the results of this research have been encountered. Allan \& Bailey [14] found that interaction and cooperation is important both within group and between groups as they give peers an opportunity to evaluate their activities during the preparation of activity-based posters. Because, students exchange ideas among themselves, ask their friends for missing topics, evaluate their friends' work, the teacher also give feedbacks as a guide to teaching and the students create better work while preparing posters in the classroom environment. Thus, this allows students to share ideas between themselves and their teachers [40]. In other words, it gives opportunity to peer learning.

The following proposals have been made for implementation by considering the results of the research. Teachers can use the activity-based posters which enhance the academic achievement of the students, they help the students to remember the subject matter longer time and contribute to the development of positive attitudes towards the students at the all stage in English classes. The students entertain by themselves, increase their success by reviewing their lesson, develop a positive attitude towards English course, they can be used an activity to further increase the communication between teacher and students and, help the teacher to understand better their students in the authentic classroom environment as well as using the posters as a tool for students to be able to act sincerely while preparing.

\section{REFERENCES}

[1] Kaya, Z, (2012). Öğrenme ve Öğretme, Kuramlar, Yaklaşımlar, Modeller, Pegem Yayıncılık Ankara

[2] Hançer, A. H., Şensoy, Ö. \& Yıldırım H. İ, (2003). İlköğretimde Çağdaş Fen Bilgisi Öğretiminin Önemi ve Nasıl Olması Gerektiği Üzerine Bir Değerlendirme. Pamukkale Üniversitesi Eğitim Fakültesi Dergisi. Yıl: 2003 (1) Sayı: 13.

[3] Rubin, Lois \& Heber, C. (1998). Model for Active Learning: Collaborative Peer Teaching. College Teaching. Vol 4, No: 1. 
[4] Berry, W., (2008). Surviving Lecture: A pedagogical Alternative. College Teaching, Vol. 56, No. 3, pp. 149-153

[5] Anthony, G. 1996. Learning in a Constructivist Framework. Educational Studies in Mathematics, Vol. 31, No. 4 (Dec., 1996).

[6] Kalem, S. \& Fer, S. (2003); "Aktif Öğrenme Modeliyle Oluşturulan Öğrenme Ortamının Öğrenme, Öğretme ve İletişim Sürecine Etkisi," Educational Sciences: Theory \& Practice 3.2 (2003).

[7] Wolfe, K. (2006) Active Learning, Journal of Teaching in Travel \& Tourism, 6:1, 77-82.

[8] Strangfeld, J. A. (2013). Student-Led Data Gathering in Undergraduate Statistics. Teaching Sociology, Vol. 41, No. 2 (APRIL 2013), pp. 199-206.

[9] Aydede, M. N. \& Kesercioğlu, T., (2012), Aktif öğrenme uygulamalarının Öğrenci Başarısına Etkisi, Hacettepe Üniversitesi Eğitim Dergisi, Ankara.

[10] Bonwell, C. C. (1999). Using Active learning to Enhance Association. Oxford University Press on Behalf of Agricultural \& Applied Economics Association.

[11] Hess G. \& Brooks E. 1998. The class poster conference as a teaching tool. J Nat Resour Life Sci Educ 27:155158.

[12] Köklü, N. (2001). Eğitim Araştırmaları Derslerinde Poster Oturumları, Ankara Üniversitesi. Eğitim ve Bilim. http://egitimvebilim.ted.org.tr/index.php/EB/article/view/52 31/1397 (Date of access:14.12.2016).

[13] Zevenbergen, R. (1999). Student Constructed Posters: A Tool for Learning and Assessment in reservice Mathematics Education. Mathematics Teacher Education and Development 1999, Vol. I, 72-83. Griffit University.

[14] Allan, C. \& Bailey, J. (2008). Students' Approaches to Poster Making. Griffith University.

[15] Crowley-Long, K., Powell, J. \& Christensen, C. (1997). Teaching Students about Research: Classroom Poster Session. Clearing House, Vol. 70, No.4: 202- 204.

[16] Lane, T. K. (2001). Promoting Posters. PAC3 at JALT 2001 Conference Proceedings. Kitakyushu, Japan. Mulnix, A. \& Penhale, S., J. (1997). "Modeling the activities of scientists: a literature review and poster presentation assignments", The American Biology Teacher, 59, ss: 482-487.

[17] Bracher, L., Centrell, J. ve Wilke, K. (1998). "The process of poster presentation: a valuable learning experience", Medical Teacher, 20, ss: 552-557.

[18] Howard, C. (2015).The Role of Posters as a means of Summative Assessment .University of Worcester. http://eprints.worc.ac.uk/3688/: Erişim Tarihi: 22.11.2016.

[19] Fuller, R. (2000). Encouraging self-directed learning through poster presentations. Proceedings of the 9th Annual Teaching Learning Forum, Perth.

[20] Jost, N. (2005). Poster Presentations and Language Teaching. In K. Bradford- Watts, C.

[21] Allen, R. F. (1994). Posters as historical documents. Social Studies, 85(2), 52.
[22] Ansell, J. ve Thorpe, J. 1984. Editor's Statment, Poster. Art Journal, Vol. 44, No. 1, The Poster (Spring, 1984), 7-8. College Art Association.

[23] Chaveznava, R. M., Yousuf, M.A. \& Caldeslast, I. (2006). Poster Sessions as a Strategy to Motivate Engineering Learning. Instituto de Investigaciones Biomédicas, UNAM, México D.F., México.

[24] Üstadal, M. K. (2009). Bilimsel Bir Posterin Hazırlanmasında ve Sunulmasında Bilinmesi Gerekenler. Erciyes Týp Dergisi (Erciyes Medical Journal) 2009; 31(3):282-290.

[25] Newbrey, M. \& Baltezore, J. (2006). Poster Presentations: Conceptualizing, Constructing and Critiquing. American Biology Teacher 68(9), 550-4.

[26] Osa, O. J. \& Musser, R. L. (2004). The Role of Posters in Teacher Education Programs, Education Libraries Volume 27, No. 1.

[27] Baird, B.N. (1991)" In-class Poster Session", Teaching of Psychology, Vol. IB: 27-29.

[28] Tanner, P., Chapmen, J. (2012). Poster Presentations Speak For Themselves, The Language Teacher, Readers' Forum.

[29] Demirel, Ö. (2011). Kuramdan Uygulamaya:Eğitimde Program Geliştirme. Pegem Akademi,Ankara.

[30] Jensen, E. (2000). Brain-Based Learning in Hardiman, M. H. (2003). Connecting Brain Research with Effective Teaching: the Brain-Targeted Teaching Model. Lanham, MD: Scarecrow Press.

[31] Hubenthal, M. (2009). Wallpaper or instructional aids: A preliminary case study of science teachers"e perceptions and use of wall-posters in the classroom (S3.10.3). Paper presented at the annual meeting of the National Association of Research in Science Teaching Annual International Conference.

[32] Chabeli, MM (2002). A poster Presentation as an Evaluation Method to Facilitate Reflective Thinking Skills in Nursing Education. Nursing Science Department, RAU.

[33] Hughes, A. (2005). A Poster Project for an Undergraduate Sensation and Perception Course. Teaching of Psychology, $32,58-59$.

[34] Eker, C. (2016). Alternatif Bir Öğrenme Aracı Olarak Kullanılan Posterlerin Öğrencilerin Akademik Başarılarına ve Derse Yönelik Tutumlarına Etkisi. Eğitimde Kuram ve Uygulama Makaleler. 2016 (12).1 103-121 ISSN: 1304-9496.

[35] Arslan, O., Keskin, N. \& Bora D., N. (2005); Alternatif Bir Öğrenme Aracı: Poster Sunum Ödevi, Milli Eğitim Dergisi, (33) 168 .

[36] Kinikin, J. \& Hench, K. 2012. Poster presentations as an assessment tool in a third/college level information literacy course: an effective method of measuring student understanding of library research skills. Journal of Information Literacy, 6(2), pp. 86-96.

[37] Altıntaş, N., N., Suer, A.,Z. , Sarı, E, S. \& U, M, S. (2014) The Use of Poster Projects as a Motivational and Learning Tool in Managerial Accounting Courses, İstanbul University, İstanbul, Turkey 
[38] Berry, J. \& Houston, K. (1995). Students Using Posters as a Means of Communication and Assessment. Educational Studies in Mathematics, Vol. 29, No. 1.

[39] Hasio, C. (2015). Visual Inspirations: The Pedagogical and Cultural Significance of Creative Posters in the Art Classroom, Journal of College Teaching \& Learning - First Quarter 12, (1), 39-44.

[40] Akister, J., Bannon, A., \& Mullender-Lock, H., (2000). Poster Presentations in Social Work Education Assessment: A Case Study. Innovations in Education and Training International, 37(3), pp. 229-233.

[41] Deutch C. E. (2011). Using Class Poster Sessions to Teach Intermediary Metabolism the American Biology Teacher, Vol. 73, No. 3, pages 174-175.

[42] Berry, J. \& Nyman, M.A. (1998). Introducing mathematical modeling skills to students and the use of posters in assessment. Primus, 8, 103115.

[43] Tapp, D. \& Martin, L. (2015). Poster Presentations, Academic-lite! The LLB Experience. Innovative Practice in Higher Education. Vol.2 (2) April 2015. Staffordshire University.

[44] Mulnix, Amy ve Sara J. Penhale (1997); "Modeling the activities of scientists: a literature review and poster presentation assignments", The American Biology Teacher, 59, ss: 482-487.

[45] Karasar, N. (2014).Bilimsel Araştırma Yöntemi:Kavramlar İlkeler Teknikler. Ankara, Nobel Yayıncılık Eğitim Danışmanlık.

[46] Büyüköztürk, Ş. (2014). Sosyal Bilimler İçin Veri Analizi
El Kitabı. İstatistik, Araştırma Deseni SPSS Uygulamaları ve Yorum.2014, Pegem Akademi.

[47] Çepni, S., Semerci, Ç., Gündoğdu, K., Sezgin, F., Demircioğlu, G.,, Köse, E., Yılmaz, A., Bayrakçeken, S. \& Yücel, C.(2008); Ölçme ve Değerlendirme. Ankara: Pegem Akademi.

[48] Tekin, H. (2000); Eğitimde Ölçme ve Değerlendirme, Ankara: Yarg1.

[49] Turgut, F., F. (1992); Eğitimde Ölçme ve Değerlendirme, Ankara: Saydam.

[50] Razali, N. M., ve Wah, Y. B. (2011). Power comparisons of shapiro-wilk, kolmogorov-smirnov, lilliefors and anderson-darling tests. Journal of statistical modeling and analytics, 2(1), 21-33.

[51] Brown,S \& Burroughs, E. (2008). Poster Projects: Mathematics in Context, PRIMUS, XVIII (5): 475-487.

[52] Eggen, P. \& Kauchak, D. (1994). Educational Psychology: Classroom connections. New York: Macmillan College Publishing Company.

[53] Doğan, A., Kaya, O. N. \& Y1lmaz, D. (2009). Elementary School Students' Experiences with Posters as an Authentic Assessment Approach in a Science and Technology Course. ESERA, İstanbul.

[54] Hunter, K. A. (1997). Poster presentations. An alternative to the traditional classroom lecture. American Journal of Pharmaceutical, 61, 78-80.

[55] Brooks. J., \& Brooks, M. (1993). The case for the constructivist classrooms, Alexandria, Va: ASCD.

\footnotetext{
${ }^{\mathrm{i}}$ This research was produced from a master thesis study.
} 